\title{
Dostępność polskich uczelni: wdrażanie art. 24 Konwencji o Prawach Osób Niepełnosprawnych (KPON) w obszarze szkolnictwa wyższego
}

\section{Streszczenie}

W artykule zarysowano społeczno-historyczne uwarunkowania, które doprowadziły do powstania i rozkwitu nowego nurtu badań nad niepełnosprawnością - Disability Studies oraz popularyzacji społecznej definicji niepełnosprawności, na której opiera się KPON. Główną część tekstu poświęcono krytycznej analizie wdrażania art. $24 \mathrm{KPON}$ w polskich szkołach wyższych z perspektywy obowiązujących aktów prawnych oraz stosowania mechanizmu racjonalnych usprawnień. Przedstawiono dane statystyczne na temat studentów i doktorantów z niepełnosprawnościami oraz zaprezentowano główne wnioski z raportów tematycznych, autorstwa Rzecznika Praw Obywatelskich oraz środowisk osób z niepełnosprawnościami. W ostatniej części artykułu omówiono wątek niepełnosprawności w świetle procesu tworzenia Ustawy 2.0 wraz ze studium przypadku poprawki nr 47.

Słowa kluczowe: niepełnosprawność, Disability Studies, Konwencja ONZ o Prawach Osób Niepełnosprawnych, KPON, racjonalne usprawnienia, szkolnictwo wyższe, Ustawa 2.0

\section{Accessibility of Polish universities: implementation of article 24 CRPD in higher education}

\begin{abstract}
The paper outlines socio-historical factors that led to the emergence of a new trend in doing research on disability issue - Disability Studies and the dissemination of a social definition of disability, on which the Convention on the Rights of Persons with Disabilities (CRPD) is based. The main part of the text provides a critical analysis of the
\end{abstract}

1 Uniwersytet Jagielloński, Wydział Filozoficzny. 
implementation process of article 24 CRPD at Polish universities with regard to relevant regulatory acts and using reasonable accommodations. Next, statistical data on students and $\mathrm{PhD}$ candidates with disabilities are presented. The main conclusions from thematic reports by the Polish Commissioner for Human Rights and by the disabled persons organizations are also presented. In the last part, the disability issue is discussed in the context of creating the Law on Higher Education 2.0 with the case study of amendment no. 47. Keywords: disability, Disability Studies, Convention on the Rights of Persons with Disabilities, CRPD, reasonable accommodation, higher education, Law on Higher Education 2.0

Głównym celem niniejszego artykułu jest krytyczna analiza procesu implementacji art. 24 Konwencji o Prawach Osób Niepełnosprawnych (KPON) w obszarze szkolnictwa wyższego.

Przyjęcie KPON przez Zgromadzenie Ogólne Narodów Zjednoczonych 13 grudnia 2006 r. było bez wątpienia jednym z przełomowych momentów dla środowiska osób z niepełnosprawnościami - co najmniej z dwóch powodów. Po pierwsze, powstał instrument prawny, który w kompleksowy sposób traktuje o niepełnosprawności (Office, b.d.w.). Po drugie, w międzynarodowym akcie osadzono nowe rozumienie tego zjawiska, akcentując jego złożony charakter, znacznie wykraczający poza cielesne doświadczenie bólu, chorowania, fizycznego ograniczenia czy nieprzystawania do kanonów piękna. W preambule Konwencji, czytamy:

„(...) niepełnosprawność jest pojęciem ewoluującym (...) niepełnosprawność wynika z interakcji między osobami z dysfunkcjami a barierami wynikającymi z postaw ludzkich i środowiskowymi, które utrudniają tym osobom pełny i skuteczny udział w życiu społeczeństwa, na zasadzie równości z innymi osobami” (Konwencja, Dz. U. 2012).

Warto zwrócić uwagę na poszczególne składowe: niepełnosprawność jest zjawiskiem ewoluującym, społeczno-kulturowym i relacyjnym, czyli powstaje w kontakcie jednostki z otoczeniem, w szczególności społecznym. Ewoluowanie zjawiska sugeruje nie tylko jego dynamikę, ale również historyczne korzenie. Studiując historię zachodnich społeczeństw, dowiadujemy się, że doświadczenie niepełnosprawności jest związane z ryzykiem marginalizacji, a nawet wykluczenia z lokalnej społeczności, rynku pracy i systemu edukacji (Barnes, 1996: 1-17). D.L. Braddock (2001: 13) okres pomiędzy rokiem 1400 a 1960 nazywa erą instytucjonalizacji niepełnosprawności, co w praktyce oznacza wypchnięcie osób zaklasyfikowanych jako odbiegające od normy do szpitali psychiatrycznych, zakładów oraz innych instytucji o charakterze opiekuńczym. Amerykański historyk D.C. Baynton (2017: 17) zwrócił uwagę, że 
przez kilka wieków niepełnosprawność była jednym z dominujących sposobów na usprawiedliwienie nierówności społecznych w amerykańskim społeczeństwie oraz stanowiła przesłankę do stosowania praktyk dyskryminacyjnych względem tej grupy osób.

Należy podkreślić, że przyjęcie KPON nie tylko sankcjonuje nowe, społeczno-prawne spojrzenie na niepełnosprawność, ale jest również zwieńczeniem kilkudziesięciu lat wysiłków niepełnosprawnych aktywistów i uczonych, skupionych wokół ruchu Disability Rights Movement oraz nurtu Disability Studies, u których podstaw leży idea społecznego modelu niepełnosprawności oraz sprzeciw wobec wszelkich form dyskryminacji ze względu na niepełnosprawność.

\section{Disability Rights Movement i Disability Studies}

Lata 60. ubiegłego wieku, uważane za symboliczny kres ery instytucjonalizacji niepełnosprawności, cechowały się rozkwitem ruchów obywatelskich oraz akademickiego zaangażowania, które zaowocowały nowym paradygmatem w badaniach nad niepełnosprawnością. Disability Rights Movement narodził się w Stanach Zjednoczonych oraz w Wielkiej Brytanii, gdzie w połowie XX wieku osoby z niepełnosprawnościami rozpoczęły negocjowanie swojej pozycji (Rembis, Pamuła, 2016: 5-25). W kręgach uniwersytetu kalifornijskiego wyrósł Independent Living Movement, którego zwolennicy postulowali równe prawa obywatelskie dla osób z niepełnosprawnościami, przede wszystkim zachowania możliwości wyboru i kontroli nad własnym życiem, deinstytucjonalizacji oraz uznania nadrzędnej, eksperckiej roli osób z niepełnosprawnościami we własnej sprawie (Nielsen, 2012). W 1983 r., na podstawie manifestu ogłoszonego przez brytyjską organizację Union of the Physically Impaired Against Segregation, powstała nowa koncepcja niepełnosprawności (UPIAS, 1976). M. Oliver (1996, 2013: 1024-1026), niepełnosprawny uczony i aktywista, nazwał ją społecznym modelem niepełnosprawności. Polega on na odrzuceniu mainstreamowego spojrzenia na niepełnosprawność jako indywidualnego, medycznego problemu, na rzecz stanowiska, że jest to efekt barier wytwarzanych przez społeczeństwo. Od tej chwili niepełnosprawność nie oznacza już uszkodzonego ciała, ale jest to rodzaj społecznej opresji, którą można teoretyzować w podobny sposób, co konstrukt płci lub rasy (Campbell, 2008: 151-162) oraz włączyć do intersekcjonalnych analiz (Ben-Moshe, Magaña, 2014: 105-114; Goethals, De Schauwer, Van Hove, 2015: 75-94).

Podobnie jak wielu badaczy z nurtu Disability Studies, moment, w którym natrafiłam na społeczny model niepełnosprawności ściągający z barków jednostki 
ciężar nienormatywności, jednocześnie lokując go w społeczeństwie, odbieram jako wyzwalające doświadczenie. Przyłączam się jednak do głosów o konieczności szerszej analizy indywidualnych doświadczeń codziennego życia z niepełnosprawnym ciałem oraz wynikających $\mathrm{z}$ nich psycho-emocjonalnych wymiarów disablizmu (Thomas, 1999, 2001: 48-58, 2004: 32-47; Reeve, 2002: 493-508, 2004: 83-100, 2014: 92-98; Crow, 1996: 55-72; Morris, 1992: 157-166). Brytyjska badaczka Carol Thomas podkreśliła znaczenie praktyk społecznych, poprzez które osoby z niepełnosprawnościami otrzymują od otoczenia negatywne komunikaty na temat własnej niepełnosprawności. Są to różnego rodzaju uprzedzenia, idee, dyskursy, obrazy oraz utarte stereotypy. Wymienione elementy stanowią istotny faktor, który również może ograniczać aktywność danej jednostki. Opisane w ten sposób uwarunkowania Thomas nazwała psycho-emocjonalnymi wymiarami disablizmu i na tej podstawie rozwinęła społeczną definicję niepełnosprawności:

"Disability is a form of social oppression involving the social imposition of restrictions of activity on people with impairments and the socially engendered undermining of their psycho-emotional well-being"2 (Thomas, 1999: 61).

Kilka lat później Thomas podkreśliła, że trafniejsze byłoby zastąpienie w jej definicji terminu disability terminem disablism, który nie tylko podkreśla procesualność analizowanego zjawiska, ale również nawiązuje do innych opresyjnych praktyk społecznych, takich jak rasizm czy seksizm (Thomas, 2007: 73). Disablizm możemy zatem rozumieć jako wszelkie praktyki społeczne, które prowadzą do ograniczenia aktywności osób z niepełnosprawnościami w jakiejkolwiek sferze ich życia oraz naruszają ich psycho-emocjonalny dobrostan.

D. Reeve (2014: 92) ocenia to jako krok do przodu względem społecznego modelu w jego pierwotnej wersji, która obejmowała przede wszystkim zewnętrzne bariery strukturalne w dostępie do edukacji, rynku pracy czy mieszkalnictwa. Model zaproponowany przez Thomas uwzględnia również wewnętrzne bariery, które mają wpływ na proces konstruowania własnej tożsamości przez jednostkę, affecting what people can do as well as who they can be (Reeve 2004: 84) 3 $^{3}$.

2 „Niepełnosprawność jest formą społecznej opresji, na którą składają się społecznie narzucone ograniczenia aktywności osób z dysfunkcjami oraz społecznie uwarunkowane obniżenie ich psycho-emocjonalnego dobrostanu" (tłum. własne).

3 „Wpływając zarówno na to, czego człowiek może dokonać, jak i na to, kim może się stać” (tłum. własne). Reeve wprowadza także rozróżnienie na pośrednie i bezpośrednie psycho-emocjonalne wymiary disablizmu: "Indirect psycho-emotional disablism is associated with the experience of structural disablism, recognising the psycho-emotional consequences of exclusion and discrimination. (...) direct psycho-emotional disablism which arises from the relationships that a disabled person has with other people or themselves and is the most important form of psycho-emotional disablism" (2014: 93). 
Reasumując, doświadczenie trwałej lub długotrwałej niepełnosprawności wymaga nie tylko nieustannego negocjowania swojego statusu społecznego, ale również stawiania oporu zinternalizowanej opresji. Posiadanie cennego kapitału w postaci wyższego wykształcenia może uczynić te zmagania równiejszymi.

\section{Disability Studies w Polsce}

W Polsce Disability Studies są relatywnie nową dyscypliną akademicką. W 2016 r. w Akademii Pedagogiki Specjalnej w Warszawie powstał pierwszy program studiów magisterskich kształcących w tym kierunku. Jest to przede wszystkim efekt rosnącego w siłę ruchu osób niepełnosprawnych oraz wzrastającego zapotrzebowania na badaczy i liderów, którzy będą mieli solidne podstawy do pracy $\mathrm{z}$ osobami z różnym typem niepełnosprawności (Głodkowska, Gasik, Pągowska, 2016: 24-35). Od kwietnia do maja 2018 r. byliśmy świadkami protestu grupy osób z niepełnosprawnościami oraz ich rodziców w budynku polskiego Parlamentu. $\mathrm{W}$ wielu polskich miastach niepełnosprawni gromadzili się na demonstracjach, wyrażając swoje poparcie dla protestujących. Jest to jeszcze jeden dowód na to, że Disability Studies są ściśle powiązane z aktywizmem i społecznym zaangażowaniem. W kontekście szkolnictwa wyższego należy zwrócić uwagę, że kluczem do rozwoju polskich Disability Studies jest włączenie w debatę akademicką osób z niepełnosprawnościami - nie tylko w roli respondentów, ale również badaczy, ekspertów i profesjonalistów. J. Rinaldi (2013: 1-16) opisuje istotę zmiany na poziomie paradygmatu jako przejście z badań robionych na temat niepełnosprawności do badań realizowanych przez i dla osób z niepełnosprawnościami. Podobną ekspercką rolę dla osób z niepełnosprawnościami przewiduje KPON. W kolejnych podpunktach preambuły czytamy:

(n) uznając znaczenie dla osób niepełnosprawnych ich indywidualnej samodzielności i niezależności, w tym wolności dokonywania wyborów,

(o) zważywszy, że osoby niepełnosprawne powinny mieć możliwość aktywnego udziału w procesie podejmowania decyzji w zakresie polityki i programów, w tym dotyczących ich bezpośrednio (Konwencja, Dz. U. 2012, preambuła).

\footnotetext{
„Pośredni psycho-emocjalny disablizm wiąże się z doświadczaniem strukturalnego disablizmu, na który składają się psycho-emocjonalne konsekwencje wykluczenia i dyskryminacji. (...) bezpośredni psycho-emocjonalny disablizm wynika $\mathrm{z}$ relacji występujących pomiędzy osobą niepełnosprawną a innymi osobami lub nią samą, co jest najistotniejszą formą psycho-emocjonalnego disablizmu" (tłum. własne).
} 
Potrzebujemy zatem niepełnosprawnych licencjatów, magistrów, doktorów i profesorów, którzy wniosą swoją perspektywę w badania nad niepełnosprawnością, czyniąc tym samym silne podwaliny do kreowania efektywniejszych programów polityk publicznych.

\section{KPON a szkolnictwo wyższe}

O edukacji na poziomie wyższym traktuje art. 24 KPON, w którym czytamy:

Państwa Strony zapewnią, że osoby niepełnosprawne będą miały dostęp do powszechnego szkolnictwa wyższego, szkolenia zawodowego, kształcenia dorosłych i możliwości uczenia się przez całe życie, bez dyskryminacji i na zasadzie równości z innymi osobami. W tym celu Państwa Strony zagwarantują, że zapewnione będą racjonalne usprawnienia dla osób niepełnosprawnych (Konwencja, Dz. U. 2012, art. 24).

W KPON zostało bezpośrednio wyrażone stanowisko dot. konieczności wspierania procesu inkluzji w obszarze edukacji wyższej. Warto zwrócić uwagę na zagwarantowane prawo do kształcenia ustawicznego, a więc nie tylko do podstawowej ścieżki rozwoju naukowego, ale również specjalistycznych programów, podnoszących kompetencje zawodowe, a tym samym wzmacniających pozycję na rynku pracy. Niezbędne dla osiągnięcia przedstawionych w ten sposób celów jest wdrożenie racjonalnych usprawnień, rozumianych jako:

„konieczne i odpowiednie zmiany i dostosowania, nienakładające nieproporcjonalnego lub nadmiernego obciążenia, jeśli jest to potrzebne w konkretnym przypadku, w celu zapewnienia osobom niepełnosprawnym możliwości korzystania $\mathrm{z}$ wszelkich praw człowieka i podstawowych wolności oraz ich wykonywania na zasadzie równości $\mathrm{z}$ innymi osobami (Ibidem, art. 2).

W obszarze szkolnictwa wyższego według przytoczonej definicji będą to procedury mające na celu adaptację toku studiów do potrzeb konkretnej osoby z niepełnosprawnością, likwidujące bariery architektoniczne, komunikacyjne, społeczne czy informacyjne. Dla zilustrowania warto podać kilka przykładów, mając jednak na uwadze, że nie wyczerpują one ani katalogu potrzeb, ani możliwych typów niepełnosprawności. W przypadku osób z niepełnosprawnością ruchu racjonalne usprawnienia mogą polegać na wykonaniu podjazdów, wind, likwidacji progów czy dostosowaniu toalet. Dla Głuchych niezbędne jest zapewnienie tłumacza języka migowego. Z kolei, jeżeli mowa o osobach z niepełnosprawnością wzroku, racjonalne usprawnienia mogą obejmować przygotowanie materiałów w formie elektronicznej 
lub w alfabecie Braille’a, zajęcia z orientacji przestrzennej w budynkach, w których odbywają się zajęcia, wprowadzenie odblaskowych oznaczeń na krawędziach schodów.

Reasumując, konsekwentne wdrażanie KPON, rozumianej w kategoriach prawa do edukacji i mechanizmów racjonalnych usprawnień, powinno wyrównać, a co najmniej w znaczący sposób poprawić, szanse osób z niepełnosprawnościami w procesie zdobywania wyższego wykształcenia i budowania kariery akademickiej.

\section{Racjonalne usprawnienia na polskich uczelniach}

Kwestię dostępności programów studiów na polskich uczelniach reguluje ustawa Prawo o szkolnictwie wyższym, w której wśród podstawowych zadań uczelni wymieniono „stwarzanie osobom niepełnosprawnym warunków do pełnego udziału w procesie kształcenia i badaniach naukowych" (Ustawa, Dz. U. 2012). Przytoczona regulacja prawna oraz art. 24 KPON stały się przedmiotem prac Komisji ds. Wyrównywania Szans Edukacyjnych, funkcjonującej przy Konferencji Rektorów Akademickich Szkół Polskich (KRASP) ${ }^{4} .2$ czerwca 2016 r. Prezydium KRASP przyjęło Uchwałę w sprawie wyrównywania szans edukacyjnych studentów z niepełnosprawnościami w dostępie do kształcenia w szkołach wyższych, w której czytamy:

„Prezydium Konferencji Rektorów Akademickich Szkół Polskich (KRASP), dostrzegając potrzebę zintensyfikowania działań na rzecz wyrównywania szans edukacyjnych studentów z niepełnosprawnościami w dostępie do kształcenia na poziomie wyższym, biorąc pod uwagę zasady działania na rzecz osób z niepełnosprawnościami, określone w art. 24 Konwencji ONZ o Prawach Osób Niepełnosprawnych, art. 70 pkt 4 Konstytucji Rzeczypospolitej Polskiej oraz art. 13 i 94 ustawy - Prawo o szkolnictwie wyższym zwraca się do uczelni członkowskich o sformułowanie i realizację - stosownie do swoich potrzeb i możliwości - oferty wsparcia dla studentów niepełnosprawnych, zgodnej tymi zasadami.

Wskazówki dotyczące kształtowania takiej oferty, przedstawione w formie 7 zasad wsparcia edukacyjnego studentów z niepełnosprawnościami, stanowią załącznik do niniejszej uchwały (Dokument nr 52, 2016).

Należy docenić, że problem dostępności szkół wyższych został dostrzeżony na szerokim forum akademickim. Nie podjęto jednak prób standaryzacji, lecz wymieniono ogólne zalecenia, które mając na uwadze autonomię jednostek akademickich,

4 KRASP to ogólnokrajowa organizacja zrzeszająca uczelnie publiczne i niepubliczne, uprawnione do nadawania stopnia doktora w co najmniej jednej dyscyplinie naukowej. 
pozostawia się do szerokiej interpretacji władzom poszczególnych uczelni. Sformułowano je jako siedem zasad wsparcia edukacyjnego:

1) indywidualizacja - przez którą rozumie się dopasowanie adaptacji do potrzeb i możliwości konkretnego studenta z niepełnosprawnością,

2) podmiotowość - jako uznanie, że osoba $z$ niepełnosprawnością jest podmiotem, a nie przedmiotem wszelkich działań w procesie dostosowania, co powinno oznaczać uszanowanie jej autonomicznych decyzji i wyborów,

3) rozwijanie potencjału osoby niepełnosprawnej w związku $\mathrm{z}$ realizowanym przez nią procesem kształcenia - co ma polegać na poszukiwaniu alternatywnych dróg realizacji poszczególnych zadań, a tym samym zdobywania wiedzy i umiejętności przez studenta z niepełnosprawnością,

4) racjonalność dostosowania - przez którą rozumie się rachunek ekonomiczny wykonywanych adaptacji, koszt oraz formę, która w możliwie dokładny sposób będzie odzwierciedlać zawartość merytoryczną zajęć, bez uszczerbku dla efektów kształcenia,

5) utrzymanie standardu akademickiego - oznacza, że wykonane adaptacje umożliwiają osobie z niepełnosprawnością nabycie pełnego zakresu wiedzy i umiejętności przewidzianych programem kształcenia,

6) adaptacje najbliższe standardowemu przebiegowi zajęć - co ma polegać na poszukiwaniu takich rozwiązań, które w możliwie najmniejszy sposób będą ingerować w formę realizowanych kursów, wyrównując jednak szanse edukacyjne osoby z niepełnosprawnością,

7) równe prawa i obowiązki - rozumiane jako równe traktowanie wszystkich studentów, bez względu na niepełnosprawność - poszanowanie przynależnych praw, jak i stawianie równoważnych wymagań (Załącznik do Uchwały 52, 2016). Wymienione wytyczne pozostają w zgodzie $\mathrm{z}$ ideą powszechnego dostępu do szkolnictwa wyższego, wyrażoną $\mathrm{w}$ art. $24 \mathrm{KPON}$. Warto przyjrzeć się bliżej, jak proces adaptacji toku kształcenia przebiega w konkretnej jednostce akademickiej. W przypadku Uniwersytetu Jagiellońskiego tę kwestię reguluje Zarządzenie nr 86 Rektora Uniwersytetu Jagiellońskiego z dnia 28 lipca 2017 r. (Zarządzenie nr 86, 2017), w którym określono szeroki zakres możliwych adaptacji, obejmujący zarówno formę egzaminów, tok studiowania, jak i otoczenie fizyczne, w którym odbywają się zajęcia dydaktyczne lub badania naukowe. Rozporządzenie odnosi się do sytuacji studentów i doktorantów, a więc dotyczy programów studiów pierwszego, drugiego i trzeciego stopnia, bez względu na kierunek czy formę kształcenia (studia stacjonarne lub niestacjonarne). W kontekście KPON należy jednak zauważyć, że rozporządzenie nie ma zastosowania w przypadku słuchaczy studiów podyplomowych, zatem nie zabezpieczono możliwości kształcenia ustawicznego dla osób, których niepełnosprawność 
wymaga skorzystania z adaptacji ${ }^{5}$. O adaptacje mogą wystąpić studenci i doktoranci, którzy posiadają orzeczenie o rodzaju i stopniu niepełnosprawności albo dysponują adekwatną dokumentacją, poświadczającą aktualny stan zdrowia, z uwagi na chorobę przewlekłą, nagłe zachorowanie lub wypadek. Sama procedura ubiegania się o adaptacje przebiega w kilku etapach ${ }^{6}$. Najpierw osoba $\mathrm{z}$ niepełnosprawnością przedkłada stosowne dokumenty do Działu ds. Osób Niepełnosprawnych UJ (DON UJ). Następnie z doradcą edukacyjnym DON UJ ustala indywidualny plan adaptacji. Pisemny wniosek studenta, po zaopiniowaniu przez doradcę edukacyjnego, jest przesyłany do właściwej jednostki administracyjnej. W przypadku studentów decyzję podejmuje dziekan właściwego wydziału, a w przypadku doktorantów - kierownik studiów doktoranckich. Po podjęciu decyzji pracownicy administracyjni jednostki, do której przypisany jest student, przekazują informację o przyznanych formach adaptacji prowadzącym zajęcia. Realizacja konkretnych form dostosowań odbywa się za pośrednictwem DON UJ. Dla przykładu, jednym z flagowych działań jest program Hamlet, w ramach którego studenci i doktoranci z niepełnosprawnościami utrudniającymi odczytywanie standardowego czarnodruku, otrzymują zaadaptowane materiały w formie elektronicznej. Należy jednak zaznaczyć, że jest to wsparcie limitowane do określonej liczby stron (1000 stron skanów, 450 stron tekstu nieskomplikowanego, 200 stron tekstu trudnego, 75 stron tekstu bardzo trudnego), grafik wypukłych (5) i opisów grafik (10), które miesięcznie może otrzymać student po przystąpieniu do programu (http://www.don.uj.edu.pl/dla-studentow/program-hamlet, 05.10.2018).

\section{Niepełnosprawni na polskich uczelniach - dane liczbowe}

Aby scharakteryzować sytuację osób z niepełnosprawnościami w polskich szkołach wyższych, warto odwołać się do zbiorczych danych gromadzonych cyklicznie przez Główny Urząd Statystyczny w odniesieniu do wszystkich publicznych i niepublicznych jednostek akademickich i instytucji naukowych (GUS, 2018b). Z najnowszych dostępnych opracowań wynika, że w 2016 r., studiowały 24403 osoby z niepełnosprawnościami, a w ich rękach pozostawało 25121 indeksów polskich uczelni. Spośród tych studentów 61 proc. (15 006 osób) kształciło się na studiach stacjonarnych

\footnotetext{
5 Jest to bezpośrednio podyktowane ustawą Prawo o szkolnictwie wyższym, w której nie nałożono na uczelnie obowiązku adaptacji programów studiów podyplomowych. W toku konsultacji społecznych nad reformą szkolnictwa wyższego - Ustawą 2.0 zostało wypracowane odpowiednie rozwiązanie, które ma regulować tę kwestię.

6 Opis procedury na podstawie Zarządzenia nr 86 Rektora Uniwersytetu Jagiellońskiego z 28 lipca 2017 r. oraz własnych doświadczeń.
} 
i odpowiednio 39 proc. (9397) na studiach niestacjonarnych. Najpopularniejszymi grupami kierunków kształcenia wśród studentów z niepełnosprawnościami były: Biznes, administracja i prawo (5929 osób), Technika, przemysł, budownictwo (3646), Nauki społeczne, dziennikarstwo i informacja (3465), Nauki humanistyczne i sztuka (2688), Edukacja (2581), Zdrowie i opieka społeczna (2503). Ponad 1 tys. studentów z niepełnosprawnościami odnotowano w następujących grupach kierunków kształcenia: Technologie teleinformacyjne, Usługi, Nauki przyrodnicze, matematyka i statystyka. Najmniej osób wybrało Rolnictwo (325) oraz Indywidualne Studia Międzyobszarowe (5). Biorąc pod uwagę rodzaj niepełnosprawności, ponad połowę (53 proc.) ogółu studentów z niepełnosprawnościami stanowiły osoby zaklasyfikowane do innych rodzajów niepełnosprawności, po czym kolejno: osoby z dysfunkcją narządu ruchu - chodzący (28 proc.), niewidomi i słabowidzący (9 proc.), niesłyszący i słabosłyszący (ok. 7,5 proc.), osoby z dysfunkcją narządu ruchu - niechodzący (ok. 2,5 proc.). Należy zwrócić uwagę, że zastosowany podział na rodzaje niepełnosprawności ma dość schematyczny i powierzchowny charakter, co w rezultacie nie daje pełnej informacji w tym zakresie - konkretny rodzaj niepełnosprawności wskazano w przypadku mniej niż połowy (47 proc.) badanej grupy. Wątpliwości budzi również brak rozbicia na podgrupy w przypadku studentów z dysfunkcjami narządu wzroku oraz słuchu, tak jak to zostało zaproponowane w stosunku do osób z dysfunkcją narządu ruchu. Każda z wydzielonych w taki sposób grup jest wewnętrznie zróżnicowana, choćby z uwagi na stopień niepełnosprawności: od osoby niedowidzącej po zupełnie niewidomą czy od osoby niedosłyszącej po Głuchą. Na tej podstawie można się spodziewać znaczących różnic w zakresie barier doświadczanych w związku z daną niepełnosprawnością, co $\mathrm{z}$ kolei jest istotnym czynnikiem $\mathrm{w}$ procesie zapewniania racjonalnych usprawnień. Niepokojący jest notowany od kilku lat spadek liczby studentów z niepełnosprawnościami - w roku akademickim 2016/2017 stanowili oni 1,9 proc. ogółu studiujących na polskich uczelniach wyższych (Ibidem: 31 ). Mniej wyczerpujące informacje zgromadzono na temat doktorantów z niepełnosprawnościami. Według danych GUS 1054 osoby spośród 43181 ogółu doktorantów pobierały stypendium specjalne dla osób niepełnosprawnych (Ibidem: 159). Trzeba jednak zaznaczyć, że prawo do takiego stypendium mają wyłącznie osoby z prawnie orzeczoną niepełnosprawnością, zatem można wnioskować, że prezentowana liczba jest niedoszacowana. Kolejnym elementem, na który należy zwrócić uwagę, jest zaobserwowana różnica w poziomie wykształcenia pomiędzy osobami sprawnymi a osobami z prawnie orzeczoną niepełnosprawnością.

Największy odsetek osób prawnie niepełnosprawnych poprzestaje na wykształceniu zasadniczym zawodowym. Co alarmujące, niemal co czwarta osoba z niepełnosprawnością (w przypadku osób sprawnych niemal co dziesiąta) ma co najwyżej 
wykształcenie gimnazjalne lub nie ma żadnego. Z kolei wykształcenie wyższe ma zaledwie co dziesiąta osoba z niepełnosprawnością, w porównaniu do 28,6 proc. osób sprawnych. Prezentowane dane dowodzą, że osoby z niepełnosprawnościami zdecydowanie szybciej kończą ścieżkę edukacji, uzyskując niższy poziom wykształcenia w stosunku do sprawnej części społeczeństwa.

Tabela 1. Struktura wykształcenia ludności w wieku produkcyjnym (w proc.)

\begin{tabular}{|c|c|c|c|c|c|c|}
\hline \multirow[b]{2}{*}{ Wyszczególnienie } & \multirow[b]{2}{*}{ Ogółem } & \multicolumn{5}{|c|}{ Według poziomu wykształcenia } \\
\hline & & wyższe & $\begin{array}{l}\text { policealne } \\
\text { i średnie } \\
\text { zawodowe }\end{array}$ & $\begin{array}{c}\text { średnie } \\
\text { ogólno- } \\
\text { kształcące }\end{array}$ & $\begin{array}{l}\text { zasadnicze } \\
\text { zawodowe }\end{array}$ & $\begin{array}{c}\text { gimnazjalne, } \\
\text { podstawowe, } \\
\text { niepełne } \\
\text { podstawoweibez } \\
\text { wykształcenia }\end{array}$ \\
\hline \multicolumn{7}{|c|}{2016 rok } \\
\hline Osoby w wieku produkcyjnym & 100,0 & 27,1 & 25,3 & 10,9 & 26,5 & 10,2 \\
\hline Osobyniepełnosprawneprawnie & 100,0 & 10,8 & 17,9 & 7,3 & 39,9 & 24,0 \\
\hline Osoby sprawne & 100,0 & 28,6 & 25,9 & 11,2 & 25,3 & 9,0 \\
\hline
\end{tabular}

Źródło: GUS, 2018a: tab. 3.

\section{Diagnoza stanu wdrażania KPON w obszarze szkolnictwa wyższego}

Monitorowaniem realizacji prawa do dostępnej i równej edukacji wyższej dla osób z niepełnosprawnościami, wynikającym z przyjęcia KPON oraz odpowiedniego ustawodawstwa krajowego, zajmują się zarówno organy instytucji publicznych, jak i organizacje pozarządowe. W 2014 r. z inicjatywy Rzecznika Praw Obywatelskich przeprowadzono ogólnokrajowe badania „Dostępność edukacji akademickiej dla osób głuchych, niewidomych, z niepełnosprawnością ruchową, chorujących psychicznie” (Trociuk, 2015). Miały one na celu nie tylko zdiagnozowanie i uwypuklenie problemów doświadczanych przez studentów z niepełnosprawnościami podczas procesu studiowania, ale również wskazanie dobrych praktyk w tym zakresie. Badania przeprowadzono na 16 uczelniach wyższych (Ibidem: 10) przy wykorzystaniu zarówno metod jakościowych (wywiady indywidualne, dyskusje grupowe i eksperckie), jak i ilościowych (ankiety CAWI). Przyjęta metodologia miała uwzględniać różnorodność perspektyw prezentowanych przez środowisko akademickie, reprezentowane przez studentów z niepełnosprawnościami, studentów sprawnych, wykładowców oraz innych pracowników uczelni. Na podstawie zebranych danych można spróbować zrekonstruować definicję (czy też model) niepełnosprawności, dominującą wśród (sprawnych) członków społeczności akademickiej. Okazuje się, że zarówno 
wykładowcy, jak i studenci sprawni postrzegali niepełnosprawność przede wszystkim w kategoriach dysfunkcyjnego ciała, które odbiega od normy prezentowanej przez osoby zdrowe. Bliżej takiemu spojrzeniu do medycznego niż społecznego rozumienia niepełnosprawności, na którym opierają się założenia KPON. Z kolei, w przypadku pytania o to, jakie są potrzeby studiujących osób z niepełnosprawnościami, głównym wątkiem w spontanicznych wypowiedziach respondentów były bariery architektoniczne. Można wnioskować, że jest to skutek zakorzenionego w naszej kulturze stereotypowego obrazu osoby niepełnosprawnej jako tej, która porusza się na wózku inwalidzkim. Jeżeli mowa o adaptacji toku i programu kształcenia, potrzebę dostępnych materiałów dydaktycznych ( $w$ tym podręczników, oprogramowania dla niedowidzących) wymieniło 10 proc. studentów sprawnych i 24 proc. wykładowców. Podobną częstość odpowiedzi uzyskano (odpowiednio 9 proc. studenci i 23 proc. wykładowcy) w przypadku dostosowania metod nauczania i egzaminowania ( $\mathrm{tj}$. utrzymywania kontaktu wzrokowego z osobą niesłyszącą, formułowania wypowiedzi w sposób zrozumiały dla osób z zespołem Aspergera, dzielenie egzaminu na części) (Ibidem: 13). Jednak 35 proc. wykładowców nie zgodziło się ze stwierdzeniem, że wszystkie materiały podczas zajęć dydaktycznych powinny być zaadaptowane do potrzeb studentów z niepełnosprawnościami. W uzasadnieniach padają następujące stwierdzenia: „[To] student powinien raczej się zaadoptować” albo: „Uczelnia ma być jednostką uczącą, a nie niańką" (Ibidem: 16). Podobne wypowiedzi mogą świadczyć o jeszcze ciągle niedostatecznej świadomości nie tylko na temat potrzeb osób z niepełnosprawnościami, ale również prawa do dostępnej edukacji i konieczności stosowania racjonalnych usprawnień.

W 2014 r. trwały prace nad Społecznym Raportem Alternatywnym $z$ realizacji Konwencji o prawach osób z niepełnosprawnościami w Polsce (Fundacja KSK, 2015). Powstawał on w procesie konsultacji z osobami z niepełnosprawnościami, przedstawicielami środowisk reprezentujących ich interesy oraz organizacjami pozarządowymi. W odniesieniu do obszaru szkolnictwa wyższego autorzy Społecznego Raportu Alternatywnego szczególnie zaakcentowali problem niedostatecznego wsparcia dla doktorantów z niepełnosprawnościami, w tym dyskryminujące praktyki w zakresie przyznawania grantów, gdzie proces aplikowania odbywa się poprzez portale internetowe, które nie są zgodne z normami WCAG 2.0 (Ibidem: 43). Zarówno w raporcie Rzecznika Praw Obywatelskich, jak i w Raporcie Alternatywnym zwrócono uwage na brak równego dostępu do edukacji ustawicznej.

Jedną z ostatnich ogólnokrajowych inicjatyw wspierających proces implementacji postanowień zawartych w KPON był projekt „Wdrażanie Konwencji o prawach osób niepełnosprawnych - wspólna sprawa”, realizowany przez Polskie Forum Osób Niepełnosprawnych od marca 2016 r. do końca lutego 2018 r. (https://www.pfon. 
org/wdrazanie-konwencji-o-prawach-osob-niepelnosprawnych-wspolna-sprawa, 05.10.2018). W pierwszej fazie projektu podjęto próbę zdiagnozowania barier charakterystycznych dla poszczególnych obszarów życia społecznego, w kolejnych etapach - poszukiwano możliwych rozwiązań. Naczelną ideą wyrażoną przez wykonawców projektu było zaangażowanie osób $\mathrm{z}$ niepełnosprawnościami w formułowanie rekomendacji prawnych oraz pozaprawnych dla 24 działów polityk publicznych, w tym szkolnictwa wyższego. W tym celu przeprowadzono debaty konsultacyjne z przedstawicielami dziesięciu środowisk osób $\mathrm{z}$ różnymi rodzajami niepełnosprawności ${ }^{7}$ oraz debaty tematyczne z ekspertami zajmującymi się tematyką niepełnosprawności w swojej pracy zawodowej, naukowej albo aktywności społecznej. Podczas debat środowiskowych omówiono propozycje rekomendacji przypisanych zbiorczo do obszaru „polityk publicznych dotyczących edukacji: oświaty i wychowania, nauki i szkolnictwa wyższego" (Kawa, Raźniewski, 2017: 26-49). Do obszaru szkolnictwa wyższego bezpośrednio odnosiły się trzy rekomendacje prawne ${ }^{8} \mathrm{i}$ dwie pozaprawne. W toku dyskusji zaakcentowano następujące zalecenia: konieczność niwelowania barier architektonicznych w jednostkach naukowych; wprowadzenie przepisów, które pozwolą na monitorowanie procesów wdrażania racjonalnych usprawnień i zasad uniwersalnego projektowania przez osoby z niepełnosprawnościami i ich organizacje; uzupełnienie programów kształcenia nauczycieli o przygotowanie do pracy z uczniami z niepełnosprawnościami. Niewątpliwie są to istotne zagadnienia, można jednak przypuszczać, że nie wyczerpują one katalogu doświadczeń i potrzeb osób z niepełnosprawnościami, funkcjonujących na uczelniach wyższych w różnych kontekstach, w szczególności studentów, pracowników naukowo-dydaktycznych czy doktorantów.

7 Realizatorzy projektu w opublikowanych raportach wymieniają następujące środowiska osób z niepełnosprawnościami: $\mathrm{z}$ niesprawnością ruchową, wzrokową, słuchową, głuchoniewidomych, $\mathrm{z}$ niepełnosprawnością intelektualną, doświadczających problemów zdrowia psychicznego, z całościowymi zaburzeniami rozwojowymi, z niesprawnością spowodowaną zaburzeniami i urazami neurologicznymi, spowodowaną chorobami przewlekłymi, z niepełnosprawnością sprzężoną i wymagającą wysokiego poziomu wsparcia.

8 Jedna z rekomendacji została uznana za zbędną przez 34,4 proc. uczestników debaty. Miała ona następujące brzmienie: „Nałożenie na rzecznika dyscyplinarnego obowiązku wszczęcia postępowania wyjaśniającego w sytuacji naruszenia przez pracownika naukowego lub badawczo-technicznego praw osób z niepełnosprawnościami $\mathrm{w}$ celu poszerzenia ochrony osób $\mathrm{z}$ niepełnosprawnościami w przypadku naruszenia ich praw przez jednostki naukowe lub instytuty badawcze prowadzące badania techniczne i społeczno-ekonomiczne". Ibidem: 34 . 


\section{Wątek niepełnosprawności w Ustawie 2.0}

Przez ostatnie miesiące w środowisku akademickim trwała gorąca debata na temat projektu nowej ustawy Prawo o szkolnictwie wyższym i nauce, zw. Ustawą 2.0. Jako członek społeczności akademickiej i zarazem osoba z niepełnosprawnością wzroku z uwagą przyglądałam się postępom w pracach nad nowym aktem prawnym oraz podjęłam próbę partycypowania w tym procesie. Moje zaangażowanie było nakierowane na sprawy doktorantów z niepełnosprawnościami oraz stosowanie postanowień zawartych w KPON.

W maju 2016 r. wyłoniono trzy ośrodki, które miały za zadanie opracować założenia do Ustawy 2.0: Uniwersytet SWPS, Uniwersytet im. Adama Mickiewicza w Poznaniu oraz Instytut Allerhanda (http://konstytucjadlanauki.gov.pl/prace-nad-reforma, 10.10.2018). Podczas konsultacji prowadzonych przez SWPS z reprezentantami społeczności akademickich i naukowych wybrzmiała kwestia równości szans edukacyjnych, rozumiana jako równy dostęp do edukacji na kolejnych szczeblach kształcenia, tj. studiach pierwszego, drugiego i trzeciego stopnia (Uniwersytet SWPS, 2017a: 17). Podobnie w raporcie przedstawionym przez Instytut Allerhanda rekomendowano przede wszystkim indywidualizację procesu kształcenia do potrzeb osób z niepełnosprawnościami, przy zachowaniu najwyższych standardów akademickich (Instytut Allerhanda, 2017: 93-94). Zwrócono również uwagę na potrzebę zabezpieczenia dotychczasowych przepisów traktujących o prawach osób z niepełnosprawnościami, jednak rozszerzając grupę potencjalnych adresatów o osoby przewlekle chore. Ponadto postulowano podejmowanie działań podnoszących świadomość w zakresie niepełnosprawności wśród członków społeczności akademickiej oraz nałożenie na uczelnie obowiązku oddelegowania odrębnego pracownika do spraw osób z niepełnosprawnościami, o ile w gronie studentów znajdują się takie osoby.

W marcu 2017 r. przedstawiono finalne projekty założeń do Ustawy 2.0 opracowane przez wyżej wymienione ośrodki (https://nkn.gov.pl/ustawa-2-0/, 10.10.2018). Jedynie w propozycji przygotowanej przez SWPS bezpośrednio podniesiono kwestię kształcenia osób z niepełnosprawnościami, powołując się na konstytucyjne prawo do równego traktowania (Uniwersytet SWPS, 2017b: 37). W obszarze finansowania uczelni podkreślono potrzebę kierowania dotacji budżetowych na „przedsięwzięcia służące studentom i doktorantom niepełnosprawnym” (Ibidem: 66). Sprawa studentów z niepełnosprawnościami została również podniesiona $\mathrm{w}$ ramach szczegółowych wytycznych do prowadzenia kierunków regulowanych i uniwersyteckich, gdzie wymieniono „opiekę i wsparcie dla studentów uwzględniające zróżnicowane potrzeby studentów, w tym potrzeby studentów niepełnosprawnych" (Ibidem: 
110-112). Ponadto postulowano stworzenie odrębnego aktu prawnego, który traktowałby o niepełnosprawności w kompleksowy sposób - ustawy o prawach osób niepełnosprawnych i postępowaniu wobec niepełnosprawności (Ibidem: 108). Jak zauważają sami autorzy projektu, nie tylko stanowiłoby to uzupełnienie do Ustawy 2.0 , ale również wniosło istotny wkład w szerszy porządek prawny.

Równolegle do prac zespołów odbywały się konferencje tematyczne Narodowego Kongresu Nauki, podczas których toczyły się dyskusje nad kształtem planowanej reformy. Aby wzmocnić stanowisko Rzecznika Praw Obywatelskich oraz środowisk osób z niepełnosprawnościami na temat implementacji KPON w obszarze edukacji wyższej, wysłałam pismo do Ministerstwa Nauki i Szkolnictwa Wyższego. W szczególności zwróciłam uwagę na następujące kwestie: uregulowanie dostępu do edukacji ustawicznej, w tym programów studiów podyplomowych; wprowadzenie obowiązkowych szkoleń dla kadry naukowo-dydaktycznej oraz innych pracowników uczelni z zakresu pracy z osobami z niepełnosprawnościami oraz stworzenie katalogu minimalnych form adaptacji, które byłyby dostępne na każdej polskiej uczelni.

We wrześniu 2017 r. przedstawiono projekt Ustawy 2.0, który wprowadzał istotne zmiany w zakresie przedłużania okresu odbywania studiów doktoranckich dla osób z niepełnosprawnościami (Projekt ustawy, 2017). Zgodnie z dotychczas obowiązującym Rozporządzeniem Ministra Nauki i Szkolnictwa Wyższego z dnia 9 sierpnia 2017 r. w sprawie studiów doktoranckich i stypendiów doktoranckich doktorant mógł się ubiegać o przedłużenie studiów o dwa lata ze względu na realizowanie długotrwałych badań naukowych. Ponadto odrębnie wymieniono cztery przesłanki, których zaistnienie uprawniało do przedłużenia okresu odbywania studiów o dodatkowy rok:

1) czasowa niezdolność do odbywania tych studiów spowodowana chorobą,

2) konieczność sprawowania osobistej opieki nad chorym członkiem rodziny,

3) konieczność sprawowania osobistej opieki nad dzieckiem do 4. roku życia lub dzieckiem posiadającym orzeczenie o niepełnosprawności,

4) posiadanie orzeczenia o stopniu niepełnosprawności (Rozporządzenie MNiS, 2017, poz. 1696, art. 7).

W projekcie Ustawy 2.0 przewidziano możliwość przesunięcia terminu złożenia rozprawy doktorskiej o dwa lata oraz wymieniono trzy przypadki, w których można wystąpić o zawieszenie studiów doktoranckich na okres jednego roku (Projekt ustawy, 2017, art. 199). Merytorycznie pokrywają się one z trzema pierwszymi zacytowanymi przesłankami rozporządzenia. Pominięto przesłankę prawnej niepełnosprawności, uchylając tym samym możliwość dodatkowego przedłużenia studiów dla doktorantów $\mathrm{z}$ niepełnosprawnościami. O istocie problemu świadczy specyfika stosowania racjonalnych usprawnień na uczelniach wyższych. Zachowanie indywidualizacji potrzeb oraz wysokich standardów akademickich wymaga ścisłej współpracy pomiędzy osobą 
z niepełnosprawnością, pracownikami dydaktycznymi oraz uczelnianymi jednostkami ds. osób niepełnosprawnych, o ile one istnieją. Dla przykładu, adaptowanie programu kształcenia do potrzeb osoby z niepełnosprawnością wzroku, zwłaszcza skomplikowanych materiałów dydaktycznych, specjalistycznej literatury, danych liczbowych lub graficznych, jest pracochłonnym i zarazem długotrwałym procesem. To dodatkowe obciążenie, które ponosi doktorant $\mathrm{z}$ niepełnosprawnością, dlatego wydłużenie okresu odbywania studiów może być interpretowane jako jedna $\mathrm{z}$ form racjonalnych usprawnień, które zgodnie z wykładnią KPON mają na celu wyrównanie szans edukacyjnych. Mając na uwadze opisane uwarunkowania, podjęłam kroki celem ochrony interesów doktorantów z niepełnosprawnościami. Dalej przedstawiam główne działania zrealizowane w kontekście trwającego procesu legislacyjnego.

\section{Studium poprawki nr 47 do projektu Ustawy 2.0}

1. Nawiązanie kontaktu $z$ biurem lokalnej posłanki. Ustawa 2.0 była już wówczas procedowana w Sejmie. Wspólne przygotowanie poprawki nr 47, która przywracała możliwość przedłużenia okresu odbywania studiów doktoranckich ze względu na niepełnosprawność (Dodatkowe Sprawozdanie Komisji, 2018: 8-9).

2. Poprawka zostaje zgłoszona przez posłankę podczas II czytania Ustawy 2.0:

„Pani Marszałek! Panie Premierze! Mam takie pytanie: Czy poprze pan projekt poprawki zgłoszonej przez Klub Kukiz'15, która przybliży nas do wykonania art. 24 Konwencji o prawach osób niepełnosprawnych? Poprawka została zgłoszona na prośbę studentów studiów doktoranckich, osób niepełnosprawnych, chodzi o to, aby umożliwić im przedłużenie o dwa lata możliwości odbywania studiów doktoranckich z uwagi na to, że podczas tych studiów bardzo często zmuszeni są poddać się rehabilitacji, kontynuować proces leczenia i niekiedy ten czas potrzebny na ukończenie studiów doktoranckich jest niewystarczający, czas taki sam, jak w przypadku osób zdrowych (...) (Sprawozdanie stenograficzne z 64. Posiedzenia Sejmu, 2018: 43).

Wprawdzie posłanka powołuje się na art. $24 \mathrm{KPON}$, jednak przedstawiając sprawę w taki sposób, nie upodmiotawia wskazanej grupy. Pozostajemy w kręgu indywidualnego, medycznego modelu, w którym osoba z niepełnosprawnością to przede wszystkim bierny pacjent, którego niedoskonałe ciało podlega technikom normalizacji. Obraz zbudowany jest na typowej opozycji „zdrowy - niepełnosprawny” (w domyśle „chory”). Społeczne bariery, na których opierają się główne założenia KPON, zostały pominięte. 
3. Przedstawienie poprawki nr 47 przez posła podczas obrad Komisji Edukacji, Nauki i Młodzieży:

Jeżeli chodzi o poprawkę nr 47, to chodzi o to, że chcemy studentom i doktorantom, którzy mają orzeczenie o niepełnosprawności, dać możliwość brania urlopów i przedłużania studiów o określony czas. Mam nadzieję, że wykażą się państwo empatią (Pełny zapis, 2018: 35-36).

Ponownie można zaobserwować elementy medycznego rozumienia niepełnosprawności - osoba z niepełnosprawnością pozostaje przedmiotem litości i współczucia, zamiast stawać się podmiotem wyposażonym w pełnię przysługujących mu praw. Poprawka zostaje zaopiniowana negatywnie.

4. Spotkanie w biurze lokalnej posłanki w sprawie form i zakresu stosowania racjonalnych usprawnień na polskich uczelniach.

5. Nieudana próba nawiązania kontaktu mejlowego z Ministerstwem Nauki i Szkolnictwa Wyższego. Zostaje umówione telefonicznie spotkanie z Rzecznikiem Praw Absolwenta w następujących sprawach: sytuacji doktorantów z niepełnosprawnościami na polskich uczelniach, wdrażania art. $24 \mathrm{KPON}$ oraz zakresu i form racjonalnych usprawnień.

6. Próba nawiązania kontaktu z członkami parlamentarnego zespołu ds. osób z niepełnosprawnością narządu wzroku. Odpowiada jedna posłanka, która deklaruje swoje zainteresowanie sprawą, jednak kontakt się urywa.

7. Podczas III czytania Ustawy 2.0 po raz kolejny przedstawiono uzasadnienie dla poprawki nr 47:

„(...) Polska ratyfikowała Konwencję praw osób niepełnosprawnych. Art. 24 mówi o racjonalnych usprawnieniach w szkolnictwie wyższym. Poprawka, którą zgłosiliśmy w imieniu niepełnosprawnych osób studiujących na studiach doktoranckich, mówi o tym, aby stworzono im możliwość przedłużenia o dwa lata tych właśnie studiów. Jeżeli pan premier nie posłuchał i nie dał racjonalnej odpowiedzi, dlaczego osoby niepełnosprawne nie mogą się o to ubiegać, jak np. osoby opiekujące się dzieckiem, to zwracam się do Parlamentu Studentów. Bardzo was proszę, aby podczas czytania senackiego w imieniu waszych niepełnosprawnych koleżanek i kolegów wnieść prośbę o przyjęcie tej poprawki (...)" (Sprawozdanie stenograficzne z 66. Posiedzenia Sejmu, 2018: 130).

W przeciwieństwie do poprzednich zacytowanych wypowiedzi w tej niepełnosprawność została przedstawiona w kategoriach równych praw oraz niwelowania barier strukturalnych poprzez mechanizm racjonalnych usprawnień. Ponadto apel do Parlamentu Studentów stanowi bezpośrednią zachętę do partycypacji $\mathrm{w}$ procesach decyzyjnych, istotnych dla całego środowiska akademickiego. 
Ostatecznie poprawka nr 47 zostaje odrzucona głosami rządzącej większości. Ustawa 2.0 zostaje przyjęta przez Sejm i skierowana do Senatu.

8. Próba nawiązania kontaktu mejlowego i telefonicznego z lokalnymi senatorami. Już po przyjęciu Ustawy 2.0 przez Senat przychodzi odpowiedź od dyrektora jednego z biur senatorskich, jednak nie odnosi się on bezpośrednio do rzeczonej kwestii.

9. Ustawa 2.0 zostaje przyjęta przez Senat. 1 sierpnia $2018 \mathrm{r}$. Prezydent RP składa podpis pod wymienionym aktem prawnym (Ustawa, Dz. U. 2018, poz. 1668).

$$
* * *
$$

Skodyfikowanie pojęcia niepełnosprawności w postaci Konwencji o Prawach Osób Niepełnosprawnych nie byłoby możliwe bez zaangażowania pojedynczych aktywistów, którzy pociągnęli za sobą całe środowiska osób z niepełnosprawnościami. To oni w połowie ubiegłego wieku rozpoczęli dyskusję na temat społecznie produkowanych, reprodukowanych i podtrzymywanych barier, a swoją determinacją doprowadzili do radykalnego przedefiniowania pojęcia niepełnosprawności, która przestała być problemem jednostki, stając się sprawą ogółu społeczeństwa. Na pograniczu nauk społecznych i humanistycznych rozwinęła się nowa dyscyplina - Disability Studies. W centrum jej refleksji znajduje się społeczny model niepełnosprawności, który wymaga rozpatrzenia perspektywy osób z niepełnosprawnościami. KPON jest instrumentem prawnym, który ucieleśnia ideały społecznego modelu. Pozwala wyjść poza ramy akademickiego dyskursu i przekraczać bariery zarówno w sferze prywatnej, jak i publicznej.

We wrześniu upłynęło sześć lat od ratyfikowania KPON przez państwo polskie, to wystarczająca perspektywa czasowa, aby dokonać krytycznej refleksji, na ile udało się nam wykorzystać ten potencjał w obszarze szkolnictwa wyższego. Analizując rozwiązania prawne funkcjonujące na polskich uczelniach, można stwierdzić, że poczyniono istotne kroki w kierunku wdrożenia mechanizmu racjonalnych usprawnień i wzmocnienia dostępu do programów kształcenia dla osób z niepełnosprawnościami. Jednak dane statystyczne, raport Rzecznika Praw Obywatelskich oraz inne opracowania organizacji związanych ze środowiskami osób z niepełnosprawnościami wskazują, że wciąż pozostaje wiele do zrobienia, zwłaszcza na polu edukacji i podnoszenia społecznej świadomości w zakresie potrzeb i praw osób z niepełnosprawnościami. Nie tylko w środowisku akademickim, ale generalnie w sferze publicznej, nadal powiela się te same stereotypowe obrazy i obiegowe opinie, co sprzyja podtrzymywaniu paternalistycznych praktyk. Głos osób z niepełnosprawnościami pozostaje na marginesie debaty publicznej. Z perspektywy osoby z niepełnosprawnością wzroku swoje zaangażowanie w proces tworzenia Ustawy 2.0 oceniam jako silnie upodmiotowiające doświadczenie. Reasumując, niezbędne jest stworzenie mechanizmu, pozwalającego 
na pełne uczestnictwo osób z niepełnosprawnościami w procesach decyzyjnych, co jest kluczowym czynnikiem warunkującym skuteczne wdrożenie Konwencji o Prawach Osób Niepełnosprawnych.

\section{Bibliografia}

Barnes, C. (1996). Theories of disability and the origins of the oppression of disabled people in Western society, w: Barton, L. Disability and Society: Emerging Issues and Insights. Longman, Harlow: Longman:1-17.

Baynton, D.C. (2017). Disability and the Justification of Inequality in American History, w: Davis, L.J., The Disability Studies Reader 5th Edition. London and New York: Routledge: 17-34.

Ben-Moshe, L., Magaña, S. (2014). An Introduction to Race, Gender, and Disability: Intersectionality, Disability Studies, and Families of Color. Women, Gender, and Families of Color 2(2): 105-114.

Braddock, D.L., Parish, S.L. (2001). An Institutional History of Disability, w: Albrecht, G.L., Seelman, K.D., Bury, M., Handbook of disability studies. SAGE Publications: 1-68.

Campbell, F.A.K. (2008). Exploring internalized ableism using critical race theory. Disability \&Society 23(2): 151-162.

Crow, L. (1996). Including all of our lives renewing the social model of disability, w: Barnes, C., Mercer, G. (red.), Exploring the Divide. Leeds: The Disability Press: 55-72.

Dodatkowe Sprawozdanie Komisji (2018). Dodatkowe Sprawozdanie Komisji Edukacji, Nauki i Młodzieży o rządowym projekcie ustawy - Prawo o szkolnictwie wyższym i nauce (druk nr 2446): 8-9, http://orka.sejm.gov.pl/Druki8ka.nsf/0/AAC0DCA52D61C081C12582AD002B4325/\%24File/2563-A.pdf, 10.10.2018.

Dokument nr 52(2016). Dokument nr 52/VI Konferencji Rektorów Akademickich Szkół Polskich: Uchwała Prezydium KRASP z dnia 2 czerwca 2016 r. w sprawie wyrównywania szans edukacyjnych studentów z niepełnosprawnościami w dostępie do kształcenia w szkołach wyższych, http://arch.krasp.org.pl/pl/archiwum_uchwaly_2012_2016/u_2012_2016,05.10.2018.

Fundacja KSK (oprac.) (2015). Społeczny Raport Alternatywny z realizacji Konwencji o prawach osób z niepetnosprawnościami w Polsce, http://monitoringobywatelski.firr.org.pl/wp-content/ uploads/2015/09/Spo\%C5\%82eczny-Raport-Alternatywny_ostateczny.pdf, 05.10.2018.

Głodkowska, J., Gasik, J., Pągowska, M. (2016). Polish Disability Studies: Inspiring Scientific Area and General Academic Profile of Study. International Journal of Psycho-Educational Sciences 5(2): 24-35.

Goethals, T., De Schauwer, E., Van Hove, G. (2015). Weaving Intersectionality into Disability Studies Research: Inclusion, Reflexivity and Anti-Essentialism. Journal For Diversity And Gender Studies 2 (1-2): 75-94.

GUS (2018a). Dane dotyczące wykształcenia osób niepełnosprawnych na podstawie Badania Aktywności Ekonomicznej Ludności (do II kwartału 2018 roku), http://niepelnosprawni. gov.pl/p,123, edukacja, 05.10.2018. 
GUS (2018b). Szkoły wyższe i ich finanse w 2016 r., https://stat.gov.pl/obszary-tematyczne/ edukacja/edukacja/szkoly-wyzsze-i-ich-finanse-w-2016-r-,2,13.html, 05.10.2018.

Instytut Allerhanda (2017). Raport z konsultacji społecznych założeń nowej ustawy prawo o szkolnictwie wyższym, https://nkn.gov.pl/wp-content/uploads/2017/02/IA-prof.-A.-Radwan-RAPORT-Z-KONSULTACJI.pdf, 10.10.2018.

Kawa J., Raźniewski, P. (oprac.) (2017). Raport podsumowujący środowiskowe debaty konsultacyjne przeprowadzone w ramach projektu: Wdrażanie Konwencji o prawach osób niepełnosprawnych - wspólna sprawa, https://www.pfon.org/images/dodatki/2017_konwencja_raport/ raport-debaty_srodowiskowe.pdf., 05.10.2018.

Konwencja (2006). Konwencja o Prawach Osób Niepełnosprawnych z dnia 13 grudnia 2006 r., Dz. U. 2012, poz. 1169.

Morris, J. (1992). Personal and Political: A Feminist Perspective on Researching Physical Disability. Disability \& Society 7(2): 157-166.

Nielsen, K.E. (2012). A disability history of the United States. Beacon Press.

Office (b.d.w.). Office of the High Commissioner for Human Rights. Understanding disability as a human rights issue, w: Monitoring the Convention on the Rights of Persons with Disabilities. Guidance for human rights monitors. Professional training series No. 17, https://www.ohchr. org/Documents/Publications/Disabilities_training_17EN.pdf: 7-12.

Oliver, M. (2013). The Social Model of Disability: Thirty Years on. Disability \& Society 28(7): 1024-1026.

Oliver, M. (1996). Understanding Disability from theory to practice. London: Macmillan.

Pełny zapis (2018). Pełny zapis przebiegu posiedzenia Komisji Edukacji, Nauki i Młodzieży (nr 141) z dnia 14 czerwca 2018 r., Kancelaria Sejmu Biuro Komisji Sejmowych, http://orka.sejm.gov. pl/Zapisy8.nsf/0/A6305F50A99825D6C12582B90046310A/\$file/0326908.pdf, 10.10.2018.

Projekt ustawy (2017). Projekt ustawy Prawo o szkolnictwie wyższym i nauce z dnia 16 września 2017 r., https://legislacja.rcl.gov.pl/docs//2/12303102/12458849/12458850/dokument309019. pdf, 10.10.2018.

Reeve, D. (2002). Negotiating Psycho-emotional Dimensions of Disability and their Influence on Identity Constructions. Disability \& Society 17(5): 493-508.

Reeve, D. (2004). Psycho-emotional Dimensions of Disability and the Social Model, w: Barnes, C., Barnes, G., Mercer, G. (red.). Implementing The Social Model of Disability: Theory and Research. Leeds: The Disability Press: 83-100.

Reeve, D. (2014). Psycho-emotional disablism and internalised oppression, w: Swain, J., French, S., Barnes, C., Thomas C. (red.), Disabling barriers - enabling environments, $3 \mathrm{rd}$ ed. London: Sage: 92-98.

Rembis, M., Pamuła, N. (2016). Disability Studies: A View from the Humanities. Człowiek-Niepełnosprawność-Społeczeństwo 1(31): 5-25.

Rinaldi, J. (2013). Reflexivity in Disability Research: Disability between the Lines. Disability Studies Quarterly 33(2): 1-16.

Rozporządzenie MNiS (2017). Rozporządzenie Ministra Nauki i Szkolnictwa Wyższego z dnia 9 sierpnia 2017 r. w sprawie studiów doktoranckich i stypendiów doktoranckich, Dz. U. 2017, poz. 1696. 
Sprawozdanie stenograficzne z 64. Posiedzenia Sejmu (2018). Sprawozdanie Stenograficzne z 64. posiedzenia Sejmu Rzeczypospolitej Polskiej w dniu 14 czerwca 2018 r. (pierwszy dzień obrad), http://orka2.sejm.gov.pl/StenoInter8.nsf/0/D7D3B4A4CC58944CC12582AD000BEDC8/\%24File/64_a_ksiazka_bis.pdf, 10.10.2018.

Sprawozdanie stenograficzne z 66. Posiedzenia Sejmu (2018). Sprawozdanie Stenograficzne z 66. posiedzenia Sejmu Rzeczypospolitej Polskiej w dniu 3 lipca 2018 r. (pierwszy dzień obrad), Warszawa 2018, http://orka2.sejm.gov.pl/StenoInter8.nsf/0/504D308A9202C85CC12582C00011DB40/\%24File/66_a_ksiazka.pdf, 10.10.2018.

Thomas, C. (2004). Developing the social relational in the social model of disability: A theoretical agenda, w: Implementing the Social Model of Disability: Theory and Research Barnes, C., Mercer, G. (red.). Leeds: The Disability Press: 32-47.

Thomas, C. (1999). Female Forms: Experiencing and Understanding Disability. Buckingham: Open University Press.

Thomas, C. (2001). Feminism and Disability: The Theoretical and Political Significance of the Personal and the Experiential, w: Barton, L. Disability, Politics and the Struggle for Change. London: David Fulton Publications: 48-58.

Thomas, C. (2007). Sociologies of Disability and Illness: Contested Ideas in Disability Studies and Medical Sociology. Palgrave: Macmillan.

Trociuk, S. (red.) (2015). Zasada równego traktowania - prawo i praktyka, nr 16: Dostępność edukacji akademickiej dla osób z niepełnosprawnościami. Analiza i Zalecenia. Biuletyn Rzecznika Praw Obywatelskich 5, https:/www.rpo.gov.pl/sites/default/files/BIULETYN_ RZECZNIKA_PRAW_OBYWATELSKICH_2015_nr_5.pdf, 05.10.2018.

Uniwersytet SWPS (2017a), Raport z przeprowadzonych konsultacji ze środowiskiem naukowym i akademickim, https://nkn.gov.pl/wp-content/uploads/2017/02/SWPS-prof.-H.-Izdebski-RAPORT-Z-KONSULTACJI-ca\%C5\%82o\%C5\%9B\%C4\%87.pdf, 10.10.2018.

Uniwersytet SWPS (2017b). Propozycja założeń do ustawy regulującej system szkolnictwa wyższego, https://nkn.gov.pl/wp-content/uploads/2017/02/SWPS-prof.-H.-Izdebski-PROJEKT-ZA\%C5\%81O\%C5\%BBE\%C5\%83.pdf, 10.10 .2018

UPIAS and TDA (1976). Fundamental Principles of Disability. London.

Ustawa Dz. U. (2018). Ustawa z dnia 20 lipca 2018 r. - Prawo o szkolnictwie wyższym i nauce, Dz. U. 2018, poz. 1668.

Ustawa Dz. U. (2012). Ustawa z dnia 27 lipca 2005 r. - Prawo o szkolnictwie wyższym, Dz. U. 2012, poz. 572 ze zm.

Załącznik do Uchwały 52(2016). Załącznik do Uchwały 52/VI Prezydium KRASP - Zasady wsparcia edukacyjnego studentów z niepełnosprawnościami, http://arch.krasp.org.pl/pl/ archiwum_uchwaly_2012_2016/u_2012_2016,05.10.2018.

Zarządzenie nr 86(2017). Zarządzenie nr 86 Rektora Uniwersytetu Jagiellońskiego z 28 lipca 2017 r., w sprawie: dostosowania procesu kształcenia i badań naukowych do potrzeb osób niepełnosprawnych oraz osób znajdujących się w szczególnej sytuacji zdrowotnej, http:// www.don.uj.edu.pl/documents/1686948/2450750/Zarz\%C4\%85dzenie+nr+86/7e8777d216cc-4e8a-b688-092710d7aaa8, 05.10.2018 